\title{
Faragó Kornélia
}

Újvidéki Egyetem

\section{Közelségek és distanciák}

\section{A térbeli létérzés határ(talanság)airól}

\author{
Az egyre gazdagabb határdiskurzusból azt szúrhetjük le, hogy meg \\ kell tanulni a határra mint komplex értelemformára, mint a \\ közömbösség jelentéseinek felszámolására, mint javaslatra, mint a \\ radikális másság igéretére, mint az át-tévedési félelmek létterére \\ tekinteni, s nem kizárólag mint akadályoztatási alakzatra.
}

\begin{abstract}
ki értelmezni kívánja a határ problémáját, annak nem, illetve nem csupán az átlépéA sére kell törekednie - egy differenciált szemlélet érdekében. Mindenekelőtt annak a gondolkodásnak a megnyitására van szükség, „melyben a határok nem korlátok, hanem kezdetek, az átkelés, a mozgás helyei”, s amely szerint „ha meg kellene határozni a modern szubjektumot, talán határszubjektum lenne" (Chambers, 2002, 471. o.), de még ezzel is csak azt mutatjuk fel, amin túl kellene lépnünk. Bár egy határszubjektumként értelmezhető ember a nyitott perspektíva összes lehetséges formáját a sajátjának szeretné tudni, sok esetben nem is az átlépést magát kívánja megélni, hanem a határok közül való kitörés lehetségességének folytonosságát. Az átlépés lehetőségét mint állandóságot, egyáltalán a lehetőségek, a nyitott perspektívák fennállását mint stabilitást. Már a bizonyosság megvonásának szimbolikus vetületei is érzékenyen érinthetik. Oto Horvat (2014) sabo megállt címü regényének (amely 2015-ben bekerült a legrangosabb szerb irodalmi díjra jelölt alkotások legszükebb körébe) első oldalán olvassuk a következő mondatokat:
\end{abstract}

„Amikor néhány nappal ezelött megkértem apámat, hogy adja kölcsön a kofferjét ehhez az utazáshoz, egy pillanatra düh és csalódottság látszott az arcán, hogy ilyesmit merészeltem kérni. A családi tabu megtört. Valamely érthetetlen okból az apám kötődött ehhez a kofferhez, habár már vagy tizenöt éve nem utazott sehová. Rendszeresen levette a szekrény tetejéröl, kiszellőztette, letörölte róla a port, de soha, semmilyen utazásra el nem indult. Úgy emlékszem, soha nem is volt nagy utazó. Emlékezetem szerint, előttem sohasem is beszélt az utazási terveiről, bár ez természetesen nem jelentette azt, hogy nem is gondolt rájuk, hogy nem érzett nosztalgiát valamely utazások iránt. Lehet, hogy ezt a koffert álombeli utazásaira őrizte."

E koffer tárgyi szimbolikájában az elbeszélés tetten éri az egykori nyitottság-élmények iránti nosztalgiát, de a jövőbeli lehetségességek biztosítékát is, az örök készenlétet az útra kelésre, a mentális valóságú terekbe való átlépés vonatkozásában is. Ha a határt az utazás-képzet szempontjából kíséreljük meg megérteni, akkor Iain Chambers nyomán örökös indulásról, a migráns perspektíva fenntartásának alapvető szükségletéröl is beszélnünk kell. A migráns perspektíváról ${ }^{1}$ mint a lét nélkülözhetetlen tartozékáról, mint egy olyan távlatiságról, amely a kimozdulás, az átlépés szükségességének és az átjutás lehetségességének a tudatában formálódik. Elbeszélések sokasága jellemzi a volt Jugoszlávia geokulturális térségeit éppen a migráns perspektíva müködtetésével.

Az apa, bár már nem vágyik utazni, „megismerni és elismerni egy távolságot, egy különbséget, amely lehetővé teszi a tapasztalatot" (Chambers, 2002, 473-474. o.), a 
lehetségesség érzésétől mégsem szeretne megválni. A koffer jel-funkciót vesz fel: az emigráns perspektíva birtoklásának tárgyi jelétől való (akár átmeneti) megfosztottság kiüresíti a lehetőség-érzet tereit. A szöveg sugallatai alapján, bár a tényleges kimozdulás igénye már régen kiveszett a figurából, mégis életbevágóan fontos lebonthatónak tudnia a „határ uralmát” (Foucault) Pontosabban a behatárolások, az elhatárolódások narratívájának uralmát. Mert maga a határ úgy is felfogható, mint a lét topológiájából kiiktathatatlan, konstitutív elem. Gondoljunk például az embert személyként, vagy mondjuk kisebbségiként definiáló határok problémájára.

„Horizontális síkon viszont a határok hasznos, sőt szükséges formái a létezésünknek: a jelenlét csak ekképpen válik lehetségessé. A behatárolások azonban a saját határaink iránti szolgálatkészséget, cinkosságot fejezik ki, a korlátozó hatalmak megkövéredését. A behatárolások a másik kizárása révén elért önaffirmációk. Az embernek nem ilyen értelemben kell konvergensnek, »monoton« és »korlátolt « individuumnak lennie." (Scrima, 1999, 53-54. о.)

A határ, bár a distinkcióról szól, alapjelentése szerint nem az átjárhatatlanságról. A megnyílás, az átjárás nehézségei nem magának a határnak a jellemzői. Ennek felmutatásához olyan alkotások felé kell fordulnunk, amelyek valamilyen módon megszabadítják a határ értelmezését az átjárhatatlanság jelentéseitől, újraolvastatják és újragondoltatják velünk a fogalom megnyithatóságának kérdéseit. Ugyanis, ahogyan egy Foucault-értelmezés láttatja, a határ ,az, ami mint életünk közelsége feltárul számunkra, a választóvonalak hálózata szerint, felosztások, összevonások, elmozdulási utak szelvényezett tereként adódik. Ha minden, ami van, határ által az, ami, és a határnak nincs határtalan forrása, akkor maga a határ

Paradoxonként érzékeljük, hogy miközben a globalizáció a határtalanság igéreteként mutatkozik, folyamatosak a határlétesítések, a falépitések, mert semmilyen hatalmi struktúra, semmilyen térhóditás sem tud meglenni a határjelentések manipulálása nélkül. A határtalanság ideológiája az áru szabad útját szervezi, s bár az emberét már kevésbé, e két vonatkozási viszonylatot folytonosan variálja, idóról idóre átmozgatja, kikövetelt nyitásokkal és váratlan gátakkal, az éppen aktuális érdek-helyzeteknek megfelelöen. Végsố soron, az áruval ellentétben, az embernek van is egy gravitációja a föld irányában, amelyet otthonának tekint, amely ilyen értelemben épül be az identitásába. Jelenkori tapasztalataink szerint a határtalanság-diskurzus, domináns gesztusaiban, tulajdonképpen újabbnál újabb határokat teremt, kidolgozva a határoltság és a határtalanság dialektikáját. a határtalan" (Sutyák, 2007, 22. o.).

A geopolitikai értelemben elbeszélt, intenzív határteremtés hatalmi jellegü. A határlétesítés ugyanis a hatalom önlétesítésének a része. Az átjutás - mint a számtalan közismert határnarratíva alapján levonhatjuk - domináns formációiban a korlátozó hatalom elszenvedése, kijátszása, leküzdése, esetleges engedékenységeinek kihasználása. Paradoxonként érzékeljük, hogy miközben a globalizáció a határtalanság ígéreteként mutatkozik, 
folyamatosak a határlétesítések, a falépítések, mert semmilyen hatalmi struktúra, semmilyen térhódítás sem tud meglenni a határjelentések manipulálása nélkül. A határtalanság ideológiája az áru szabad útját szervezi, s bár az emberét már kevésbé, e két vonatkozási viszonylatot folytonosan variálja, időről időre átmozgatja, kikövetelt nyitásokkal és váratlan gátakkal, az éppen aktuális érdek-helyzeteknek megfelelően. Végső soron, az áruval ellentétben, az embernek van is egy gravitációja a föld irányában, amelyet otthonának tekint, amely ilyen értelemben épül be az identitásába. Jelenkori tapasztalataink szerint a határtalanság-diskurzus, domináns gesztusaiban, tulajdonképpen újabbnál újabb határokat teremt, kidolgozva a határoltság és a határtalanság dialektikáját.

Másként rajzolja ki az átlépés helyét és idejét a kívüliség megélésének vágya, és megint másként a távozás megtapasztalásának kényszere, az előzményi kontextusok, az egyéni motivációs állapotok, az egyéni és a közösségi narratívákban kirajzolódó jelentéstartalmi sajátosságok milyensége. Az átlépés mint önkéntes téri választás a személy önmagán való túlterjedésének lehetőségével, saját kontextusainak a kiterjesztésével kecsegtet. Az identitásváltozatok közti választás lehetőségének az érzete mindig kiváltja a mérlegelö gyötrődést. A helyváltoztatás, az intim közelségek, a tágítási tendenciák, a szükös hermeneutikai mozgástér bővítésére való igény, a területkiterjesztési vágy, a radikális másság ígérete segíti a térváltásra való elhatározást. Aki elszánja magát az átlépésre, tisztában van azzal, hogy veszteségeket kell megélnie. A veszteségeket az új, pozitív tapasztalatok sem pótolhatják, mert a veszteségek pótolhatatlanok. Ezek a kettősségek létmeghatározó feszültségeket teremtenek. E feszültségek csökkentésére a szubjektum érzelmi tudatában hordozza mindazt, amitől eltávolodott, s tárgyakat vesz magához. A kofferrel a családi történet egy részét viszi magával, hogy, mint mondja, az idegenben való tartózkodása könnyebb legyen. „Lesz egy olyan tárgyam, amely közvetlen kapcsolatban van a múltammal, azzal, ami vagyok, azzal, aminek hiszem magamat." (Horvat, 2014 , 8. o.) Nyilvánvaló, hogy a koffer egy olyan tárgyi elem, amely képes ellátni a migráns perspektíva szimbolikus képviseletét is.

E tanulmány keretei nem teszik lehetővé, hogy az átlépés az identitás társas-téri konstrukciójának megváltozását illetően is értelmezést nyerjen. Mindenesetre szögezzük le, hogy az új dimenzióba való áttérést a búcsú érzelemvilága szinte mindig beleágyazza a kérdésbe, hogy mivel kárpótolhat a távolság, amely felszámolja a testi kontaktus lehetőségét, és kizárja az érzékszerveket az elhagyottak további megismeréséből, az arc aktivitását, a szaglást, a tapintás intimitását? A távozás nyomán létesülő írásos kommunikáció is rávilágít a hollétek eltérő szemantikai viszonyaira, minden egyes kérdéshez más értelmezési terepet nyújt az előzményektől való térbeli elszakítottság, a felidézett kontextus halványulása, a közös evidenciabázis lassú kiürülése, elhomályosulása, vagy éppen megtagadása. A szemantikai összehangoltságok gyengülésével megváltoznak a hangsúlyok. Az is bizonyos, hogy más a jelentéstartalmi konszenzus fenntartására való törekvés, más a távolság viszonyszabályzó ereje az ideiglenesnek tervezett, mint a véglegesnek tünő helyváltoztatás esetében. Mindkét esetben másként müködik a distancia mint inspirációs forrás.

A narratív én-reprezentációk egyik eszköze és célja annak a felvázolása, hogyan viszonyul, hogyan viszonyulhat az alany a saját határaihoz, illetve ahhoz, ami távolságot tart vele szemben, és hogyan a közeli, az öt közvetlenül övező vonatkozásokhoz, szükebb léttereinek szigorú körülrajzoltságához. Ami nem enged közel magához, az bizonyosan felkelti azt a vágyat, hogy egyre közelebb menjünk hozzá. A térváltás aktusában olykor egyszerủen csak a szorító, sőt fojtogató közelségek elviselhetetlensége kerül elutasításra:

„Nálam mindig már a kezdetekben megjelenik az a brutális, irracionális vágy, hogy megtagadjam, ellökjem azt, ami közel van (beleértve a valóságos világot is) és elmenjek valahová máshová - ahogyan az is, hogy a végük felé taszítsam a dolgokat, hogy a túloldalra kerüljek." (Baudrillard, 2000, 113. o.) 
Az átkerülési mozzanatnak és a túloldaliságnak a felvillantása bevezeti a határjelentés dialektikus mivoltának a témáját. Szinte megköveteli, hogy szót ejtsünk arról, hogy ha az elbeszélés a tapasztalat határairól beszél, a belüliség élményéről, akkor természetszerüen feltételezi a külső, a kívüliség létezését is. Az átléptetés poétikai művelete nem türi a tértelenség képzetét. A mai kommunikációs térátjárások révén a dichotómiák mozgásának a dekonstrukciója sem maradhat ki a gondolkodásból, az itt-ott, a közelség-távolság kettősségének viszonylagos bonyolultsága. A határ dinamicitásában tükröződő kettősségek az elválasztó funkció mellé emelik az összekapcsoló funkciót is. Maga az átlépésképzet is valamiféle behatároltságról szól, de oly módon, hogy egyben szóba hozza a megnyílás képzetkörét is, a „másik tér” meglétének bizonyosságát. A saját határaink átlépésének vonatkozásban is. Mindig fel kell tennünk a kérdést, hogy a test vagy csupán a szellem szinekdochés mozdulata-e a térátlépés. Összetettebb látás- és beszédmódot követel meg, ha a test és a szellem közös akciói komplex jelentésállományként építik az elbeszélést.

Van Tolnai Ottónak egy szövege $A$ pompeji szerelmesek címü kötetben, Tigristincs a címe, amelyben (az elbeszélő egy korábbi novelláját felidézve) folyamatosan munkálnak az átlépés, a távolságteremtés, az országból való „kiverekedés” mozzanatai. Orosz István elhatározza, hogy távozik az országból: „Örökre Amerikába költözik” (Tolnai, 2007 , 6. o.). Azokat a mondatokat idézem, amelyekkel a térbeli elszakadásra való felkészülést mint az odatartozási reflex megnyilvánulását közvetíti a narrátor, egy sajátos egzisztenciális térközben tartva Orosz Istvánt. A migráns perspektíva keresi itt a helyét a geokulturális kötöttségek viszonyhálójában. A köztes-testiség legintenzívebb szellemi pillanatait ragadja meg az elbeszélés. Orosz ugyanis már eladta a házát, de az indulás napjának hajnalán, mielőtt barátaival a belgrádi repülötérre indult volna,

„még egyszer utoljára, szépen, aprólékosan felsöpörte a ház előtti gidres-gödrös téglajárdát. A novella valójában erről a különös reflexről szólt. Arról az utolsó söprögetésről. Ő akkor nem tudhatta, hogy valóban az utolsó, nem tudhatta, hogy Amerikában nincsenek járdák. Arról, ahogyan évtizedek során beidegződött mozdulatokkal, ritmusban haladt tégláról téglára. [...] Akárha minden egyes téglától búcsút akart volna venni, mert már rég nem voltak egyformák, sok eltörött, akárha valami hernyótalpas lény, amfíbia talán, mászott volna végig rajtuk, sajátos profilt kaptak az idő folyamán. Nem kerti söprüt használt, piros nyelü cirkot, amilyennel a bolt olajos padlóját is söpörte, ugyanis városkánk messze híres volt a söprügyáráról. Az a járda azért volt olyan különös, erről persze nem érkeztem említést tenni abban a novellában, mert túlégetett téglából készült, majdhogynem klinkerből, amelyhez a téglagyári munkások könnyen hozzájutottak." (Tolnai, 2007, 6-7. o.)

A másság vonatkozásában kibontakozó értelem-összefüggések az identitás képzetét megalapozó járda kapcsán jelennek meg. Az eljövendő másik térben nincsenek járdák, az évtizedek során beidegződött mozdulatok elveszítik irányulásuk tárgyát. A hiánymozzanatot éppen abban jelöli meg az elbeszélö, ami az otthoni terekhez való mély odatartozás jelölője, amely kiváltja az utolsó, meghitt kontaktusban tetten érhető búcsú gesztusát, a söprögetési reflexet. Orosz tégláról téglára halad, mert különböznek ezek a szimbolikus mintázatok, és a létalap minden dimenziójától szeretne búcsút venni. Az elemek „sajátos profilt kaptak az idök folyamán”, és így egyenként kötődik a mozaik minden eleméhez. A klinker szilárd és tartós alapot biztosít az emberi létezéshez, s otthoni terekben viszonylag könnyen hozzá is lehet jutni. Az idegen tériességnek egy kevésbé biztonságos rendje rajzolódik ki, hiszen a térátlépéssel előálló járdahiány éppen ezt a szilárd talapzatot vonja ki a jövő létteréből. Az idők folyamán bevésődő sajátos profilokat. Az olyan, hosszadalmasan kiformálódó minőségeket, amelyeket az átlépéstől számítandó, múlthiányos időkben mindenképpen nélkülözni kell. 
A térátlépések céljai és indokai sokfélék, a figurák a szabadságszerzés külső tereibe lépve olykor éppen a radikális másság metaforáit keresik, ahogyan az imént idézett Jean Baudrillard (2000, 115. o.) fogalmaz:

„Nem szerezhetünk meg több szabadságot innen belülről, már semmit sem szerezhetünk meg többé belülről. Akkor már inkább átmegyek egy másik világba, egy radikális másságba, amelynek nincs szüksége rám ahhoz, hogy létezni tudjon - és ennek a másságnak a szememben Amerika a metaforája."

A kivonulás, a térelhagyás antropológiai tértapasztalata az irodalmi reprezentációban sokszor nyer patetikus értelmezést. Általában véve megrendítő az az érzéskomplexum, amit a határzónában látunk kibontakozni. Az elöbbi Tolnai-féle betéttörténet finom pátoszát építi majd le a továbbiakban a határtapasztalat ironikus-szarkasztikus megjelenítése, amikor hímzett vászonzacskóba töltött, istentelenül büdös „tigristinccsel”, azaz tigrisürülékkel küldi a szereplöit a határzónába, és így, a rendőrkutyák elrettentésével hajtatja végre a sikeres határátlépési kísérletet (három sikertelent követően), eltörölve az átjutás minden emelkedettségét. Eltörölve a határsértés közhelyesen felemelő izgalmainak unalmát, a határ fetisizálása ellenében hat az elbeszélés. Az ironikus határátlépő gesztus szubverzív energiákat hordoz: ameddig ugyanis fetisizáljuk, addig erösítjük a határ hatalmi mechanizmus-rendszerét.

$\mathrm{Az}$ is felmerül a történetben, szinte észrevétlenül mélyítve az iróniát, hogy általában véve egy ilyen zacskóval kellene közlekedniük a szereplőknek, vagy egyenesen be kellene kenni magukat a zacskó tartalmával, a szabad mozgásvonalak, az átjárhatóságok, a határtalanságok megteremtésének érdekében. A foucault-i gondolatmenetet parafrazeálva a határ leginkább abban a gesztusban létezik, amely „diadalmasan átmetszi és megtagadja".

„A határ és a határsértés egymás adósai létük sürüségéért: nem létezik határ, amely tökéletesen áthághatatlan volna; ugyanakkor üres hivalkodás lenne a határsértés, amely csupán egy illuzórikus vagy árnyszerü határt hágna át. Ám létezik-e igazán a határ azon gesztuson kívül, amely diadalmasan átmetszi és megtagadja? [...] Vajon nem merül-e ki a határsértés abban a pillanatban, amikor áthágja a határt, hiszen az idő eme pontján kívül sehol sem létezik?” (Foucault, 1999, 74. o.)

Ezért nem szabad az átlépést diadalra juttatni, ezért kell az ironikus szférában tartani az átmetszés tényét. Amely narratívák hagyják, hogy a határ-átlépés patetikus vonatkozásrendje szervezze a gondolkodást, azok tulajdonképpen affirmálják az elkülönülések értelemszféráját. A határsértés csak átüti egy villanásnyi időre a zárlatot, de a megsemmisítésére nem törekszik ,,a határsértés újra meg újra nekiveselkedik, hogy áthágjon egy vonalat, amely azonmód összezárul mögötte, emlékét is alig örizve az elbizonytalanodásnak, s amely újra visszavonul, egészen az áthághatatlanság horizontjáig" (Foucault, 1999, 74. о.).

A pompeji filatelista címü Tolnai-szöveg elbeszélője szorosan egymás mellé helyezi a határtalanság és a határoltság élményét, s megmutatja, hogy milyen könnyen fordul át az egyik a másikba, mintha az egyik meglenne a másikban. Azt is mondhatnánk, hogy A pompeji filatelista a határmentiség léttudatát az át-tévedés félelmeinek elbeszélésével közvetíti, formázza meg. A határsáv olyan gondolatokat hív életre, amelyek két elhatárolódási tendencia mezsgyéjén a térbeli létérzés határ(talanság)airól szólnak, egy olyan kettősségről, amelyben a határtalan és a behatárolt egymás felé orientálódnak, majdnemhogy egylényegüek. Az elbeszélő vízililiomért megy be a tóba: 
„próbálok gyorsan kicibálni néhányat, [...] az észbontó rizómaszövedékből. Hiszen ez a rizóma [...] morfondírozom nyakig vízbe merülve immár, hihetetlenül összefüggő szőnyeget képez. semmi sem tagolja, határolja... Éppen amikor kezemben a szép csokorral el akarok indulni kifelé, egy félig megdőlt karóra leszek figyelmes. Már elöbb is észrevettem, amikor megcsúsztam, benne akartam megkapaszkodni. De úgy tünt, már eldülőfélben van, inkább megmerültem egy kicsit. A felső részén három csík: kék-piros-fehér. Nem a határ ez már itt, szólok ki, pánikomat leplezve, a csokor mögé dugva sáros arcom, Jutkának. De úgy tünik, mondja, nehogy beljebb menj! [...] Remélem, mondom, félve lépkedve kifelé a gyönyörü sárga liliomokkal mellemen, nincs elaknásítva, nem maradt itt egy-két akna a vasfüggönyből, mert, minden jel szerint, a vasfüggöny aknagumói a rizómaszőnyeget sem kímélnék, felszaggatnák, egyedül talán csak azok lennének képesek felszaggatni, tagolni..." (Tolnai, 2007, 85. o.)

Az elbeszélő, a gyönyörü sárga liliomokkal a mellén, a határtalant hordozza, azt a rizóma-képzetet, amelyet semmi sem tagol, semmi sem határol, de amelyet az elaknásítás, a határ-gondolkodás radikális megnyilvánulása bármely pillanatban szétroncsolhat, kitehet a drámai széttagolódásnak, a tragikusan új forma-képződésnek.

Szót kell ejteni arról is, hogy a határ, „egy másik világot” körvonalazva, bevezeti a megkülönböztetés fogalmát. A határ nem más, mint a megkülönböztetés, az elkülönítés, az egyedítő feltárás egyik alapeszköze: túljutva rajta, a szubjektum önmagától is elkülönböződik. Ebben rejlik az átlépés frenetikus élményisége, öröme, illetőleg tragédiája. Egy lehetséges értelmezés szerint a kulturális térképzéssel előálló megkülönböztetési kényszer, a végtelen perspektívával szemben, kiírja a világból a közömbösség jelentéseit. Újra Baudrillard-ra hivatkoznék, aki szerint a végtelen perspektíva terepe, amit ő a sivatagi térrel azonosít, a közömbösség jelentéseihez köthető. „Amikor a civilizált világban bármiféle szabadsággal akarunk gondolkodni, komoly erőfeszítéseket kell tennünk, hiszen a megkülönböztetés kényszere és a kultúra azonnal sarokba szorít minket" (Baudrillard, 2000, 108. o.). Amerikai tapasztalatai kapcsán mondja, hogy az, amit itt tapasztalt meg, az ember egyfajta „különbségen túli állapotban”, az „,nem filozófiai, hanem inkább térszerü, mobil szabadság, a test és a mozgás szabadsága" (Baudrillard, 2000, 110. o.). Minthogy azonban annak is meg kell nyilvánulnia, hogy a test végtére is kulturális reprezentáció, törekvéseinknek arra kell irányulniuk, hogy felfedjék a filozófiai szabadság szféráját, amely nem egyenlíthető ki a térszerü, a mobil szabadsággal, a test és a mozgás szabadságával. Az absztrakt térszerüség fogalmiságot nem tud teremteni, s vannak olyan gondolkodások is, amelyek szerint a sivatagban mint kultúra- és ideológiahiányos térben a hatalom alternatívái sem képződnek meg.

A térátlépésre összpontosító narratíva-elemzések jelentékeny különbségként mutatják fel, hogy az odaátival való kapcsolat megragadása-e a cél, a lelassult, vagy teljesen lebénult otthoni tapasztalat mozgásba hozása, vagy éppen az innenső oldallal való teljes szakítás, az eltávolodás, a puszta kívülre kerülés. A távolságok eltörlésére irányuló kísérlet is átlépésekkel jár. Az átlépésben már a legközelebbi is úgy értelmeződik, mint a határ túloldala. A terek közti váltás, az egyik térből a másikba való átlépés úgy is megjelenhet a történetben, mint az egyoldalú perspektívák fogságából való kilépés, a tudásszélesítés aktusa, amely aktus nyomán konstitutív változás játszódik le. Gondoljunk például azokra az elbeszélésekre, amelyekben a határsértőt, akinek hősiessége, tragédiája éppen ennek a választóvonalnak a természetéből fakadhat, a határ hozza létre. A térátlépések a tapasztalat feldarabolódását hozzák magukkal. A tapasztalat alanyának a darabokra törését, tulajdonképpeni önelvesztését: 
„miközben a határsértő úgy tesz, mintha elfoglalna egy területet, valójában szétszórja szubjektumát a határ két oldalára, itt is van, ott is, ide-oda siklik, csak éppen nem ugyanaz a szubjektum immár; észrevétlenül darabokra tört a tapasztalat alanya... [...] A határ olyan tapasztalat, ami feldarabolja a tapasztalót - ez az ára a határsértésnek" (Sutyák Tibort idézi Deczki, 2008, 178. o.)

Ezek a mondatok egy szélesítő gondolkodásban azt is megvilágíthatják, hogy miért kelnek útra azok, akik valamilyen csalódásból, valamilyen sikertelenségi élménykörből szeretnének kilépni. Az általában önkereső, sőt önmegtaláló jellegünek felfogott utazás ebben a gondolkodásban átalakul. Vagyis az önismereti szembesülést egy önelvesztési folyamat részeként jelenítheti meg az elbeszélés. A térátlépés tapasztalatát felvállalók, az önmaguktól való megszabadulást keresve, voltaképpen a „darabokra törés egzisztenciális kalandját" (Deczki, 2008, 179. o.) élik meg, mint ahogyan a tudásszerzés vonatkozásában megfogalmazódik:

„ki kell lépni a szabály, a rend, a norma területéröl, majd visszatérni; ide-oda ingázni a határ két oldalán. Míg közben szép lassan és biztosan elveszítjük önmagunkat" (Deczki, 2008, 178. o.)

Az önmagát vesztett én másikként áll szemben a Másikkal. A transzperszonális problémák felmerülése, a testi részvétel a másik életében, a közös tér filozófiája, a másik terébe való behatolás, de az elhagyott közös tér felszámolódása is bevonhatja a beszédrendbe a proxematikai gondolkodást. A közvetlen testi reprezentáció felől tekintve a határértelmezés olyan új vonatkozásai is kibontakozhatnak, amelyek föként az arcról szólnak mint a behatároltság meghaladásnak eszközéről.

„A határok kialakulnak. A határok javasolnak. De nem kényszerítenek, mert akkor megszünne a szabadság, a lét »állapota«. A határok arcot javasolnak neked. Az arc pedig a nárcizmus patológiáját leszámítva az első kilépés a behatároltságokból, a behatároltság meghaladása. Mivel az arc a másik felé van fordítva, túl az individuális behatároltságokon. Látok, így a mindennel lépek kommunióba." (Scrima, 1999, 54. o.)

A kérdés csak az, hogy az átkerülés átalakulásaiban a szakítás - újra-elhelyeződés intenzitásában formálódó arcnak vannak-e olyan aspektusai, amelyek képesek felszakítani önnön határait. A kitörlődőfélben lévő, illetve kitörölt arcnak van-e tekintete?

\section{Irodalomjegyzék}

Baudrillard, J. (2000 ): Az utolsó elôtti pillanat. (A közömbös paroxista). Magvető Kiadó, Budapest.

Carter, P. (1992): Living in a new country. History, Travelling and Lanuage. Faber\& Faber, London.

Chambers, I. (2002): Vándorlás, kultúra, identitás. Helikon, 4. sz.

Deczki Sarolta (2008): Megszabadulni önmagunktól. Asapecto, 1. sz.

Foucault, Michel (1999): Előszó a határsértéshez. In: uő: Nyelv a végtelenhez. Latin Betük, Debrecen.
Horvat, O. (2014): sabo je stao. Agora, Zrenjanin Novi Sad.

Scrima, A. (1999): Az idegen és a zarándok. Koinónia Könyvkiadó, Kolozsvár.

Sutyák Tibor (2007): Michel Foucault gondolkodása. Attraktor, Máriabesenyő-Gödöllő.

Tolnai Ottó (2007): A pompeji szerelmesek. Fejezetek az infaustusból. Alexandra Kiadó, Budapest. 


\section{Jegyzetek}

1 „Egy autentikus módon migráns perspektíva talán azon a megérzésen alapul, hogy az itt és ott közötti oppozíció maga is kulturális konstrukció, annak a gondolkodásnak a következménye, amely rögzített entitásokkal dolgozik és oppozicionálisan határozza meg őket. Kezdődhetne azzal, hogy a mozgást nem az indulás és az érkezés rögzített pontjai közti kényszerü átmenetnek tekinti, hanem a világban való létezés egy módjának" (Carter, 1992, 101. o., idézi: Chambers, 2002, 473. o.) 